\title{
Interference between pier models and its effects on scour depth
}

\author{
Rahul Malik ${ }^{1} \cdot$ Baldev Setia ${ }^{1}$
}

Received: 23 July 2019 / Accepted: 7 December 2019 / Published online: 11 December 2019

(c) Springer Nature Switzerland AG 2019

\begin{abstract}
Excessive scouring of sediment around bridge piers plays a major role causing failure of waterway structures. To prevent scouring around bridge piers, it is necessary to determine the maximum scour depth. In the past, researchers have conducted extensive laboratory work around flow structures with the help of scaled models. But most of the work has been carried out around an isolated pier and the work around a group of piers is relatively much lesser. To fill up the gaps in information, an experimental study was conducted in a recirculating water flume $15 \mathrm{~m}$ long, $0.4 \mathrm{~m}$ wide and $0.6 \mathrm{~m}$ high containing uniform sediment of mean size, $d_{50}=0.30 \mathrm{~mm}$. Experiments on cylindrical pier models of size $42 \mathrm{~mm}$ were run at a velocity equal to 0.89 times the critical velocity, $u_{c}$. Three different arrangements i.e. Tandem, Side by Side and Staggered have been used to analyze the effect of spacing and orientation on scour. From the initial observations it was concluded that, in the case of Tandem arrangement when the spacing between the piers was 16 times the diameter of the pier and more, both the piers showed independent behavior. But if the spacing between the bridge piers is $0 \mathrm{D}$, then both the piers behave like a single pier and the scour depth was found to be $41 \%$ greater than that of a single pier. However, when the clear spacing was greater than 1.5 times for side by side and 2.5 times for staggered arrangement, the piers behaved independently.
\end{abstract}

Keywords Scour $\cdot$ Interference $\cdot$ Pier $\cdot$ Ansys 18.0

\section{List of symbols}

D Pier diameter

$\mathrm{V} \quad$ Velocity of flow

$L \quad$ Length of flume

B Breadth of the flume

$\mathrm{H} \quad$ Height of the flume

$\mathrm{d}_{50} \quad$ Median size of sediment

d Depth of flow

$\mathrm{s} \quad$ Spacing between the pier models in

side by side arrangement

$\mathrm{T} \quad$ Spacing between the pier models in tandem arrangement

$\mathrm{S} \quad$ Spacing between the pier models in staggered arrangement

$\theta \quad$ Angle between the two piers in staggered arrangement

$\mathrm{F}_{\mathrm{r}} \quad$ Froude number
Hsu1 and Hsd1 Depth of Scour around upstream and downstream bridge piers, respectively in tandem arrangement

Hsl1 and Hsr1 Depth of Scour around left and right pier in side by side arrangement Hsf Depth of Scour around front pier in staggered arrangement

Hsr1 and Hsr2 Depth of Scour around rear piers in staggered arrangement

$\mathrm{R} \quad$ Coefficient of determination

\section{Introduction and literature review}

Bridges play an important role in ensuring the convenience of people in transportation of vehicles and goods across waterways. The effective useful life of a bridge may

Rahul Malik, rahul_6150023@nitkkr.ac.in; Baldev Setia, setia@nitkkr.ac.in | 'Department of Civil Engineering, National Institute of Technology Kurukshetra, Kurukshetra 136118, India. 
generally be about 70 years for the super structure and about 100 years for the substructure. However, while one bridge may keep performing its functions satisfactorily one or more bridges may be constructed in its vicinity owing to newly laid railway, highway etc. to take care of the increase in traffic. Ultimately, it results in a number of bridges close to each other, interference of which, with each other might not have been considered during the architectural or hydraulic design. This phenomenon may be most observed in developing countries where partially serviceable bridge may not be demolished. Failure and damage to most of the bridges occurs during floods. The problem of floods combines with the unaccounted effect of interference may cause huge damage. The severe floods during September 2014 in the valley of Kashmir caused wide spread damage to bridge and road. Wardhana and Hadipriono [1] reported that about $48 \%$ of bridge failures in the US were caused due to floods and corresponding scour in the rivers. The data regarding bridge piers and their possible causes has been presented in Fig. 1.

Numerous laboratory investigations around an isolated model bridge pier have been carried out by a number of investigators to study the mechanism of scour and to calculate the maximum scour depth. Notable contributions include Laursen and Toch [2], Melville [3], Ettema [4], Melville and Sutherland [5], Breusers and Raudkivi [6], Dey et al. [7], Hoffman and Verheij [8], Setia [9], Muzzamil and Gangadharaiah [10], Barbhuiya and Dey [11], Gangarudraiah et al. [12], Ismail et al. [13] and Malik and Setia [14]. However, work and hence established knowledge about scouring around a group of piers is relatively lesser and hence more research is required in this direction.

Hannah [15] was perhaps the pioneer who discuss about the local scour at a group of small diameter piers. From the experimental results author concluded that after $7 \mathrm{~h} 80 \%$ of the equilibrium scour depth was achieved. His major contribution was in the form of identification and description of the four types of the mechanisms which affect scour depth at pier groups but are not present in scouring around an isolated pier. These mechanisms are

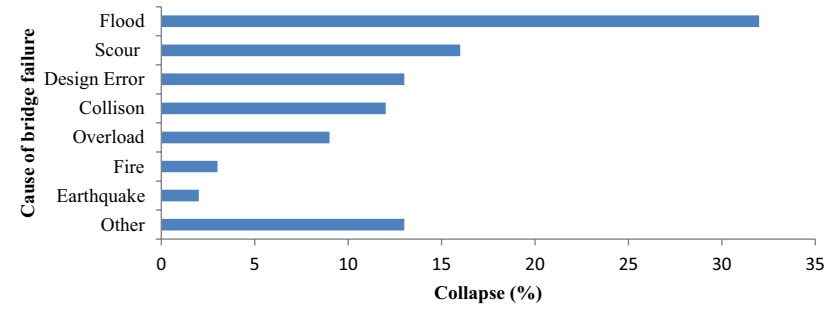

Fig. 1 Distribution of causes of bridge failure during the period between 1989 and $2000[1] \theta=120^{\circ}$
Reinforcing effect, Sheltering effect, Shed vortices and compressed "horseshoe vortex".

Haghighat et al. [16] also conducted an experimental study on a group of piers. They replaced a cylindrical shaped pier of diameter $b$ by a group of small piers of diameter $0.302 \mathrm{~b}$ each placed at an angular spacing of $120^{\circ}$. Four different sizes ranging from 0.775 to $1.844 \mathrm{~mm}$ median diameter were used. Scour at the pier group and the pier of diameter of the circumscribing circle was determined under identical flow conditions. It was found that the relative scour ratio, the scour of group of piers to the solid single pier, was about 0.61 . This could be on account of lesser width of pier facing the flow in comparison to two or three such piers placed together. Also, two small piers spaced from each other will lower the magnitude of adverse pressure gradient in comparison to that developed on the upstream of a single pier of equivalent size. A line diagram of three piers has been shown in Fig. 2.

Khaple et al. [17] the authors have been conducted an experimental study on group of piers in tandem and staggered arrangement to calculate the scour depth. They concluded that the scour depth at the rear pier was differs from 0.8 to 0.87 times the scour depth occurs at the isolated bridge pier. The minimum value for the scour depth around two piers in a line occurs at a spacing of $8 D$ ( $D=$ Diameter of the pier). In staggered arrangement, as the distance between the piers increases, the maximum scour depth at the rear piers decreases. Realizing the fact that through significant work had been conducted around a single pier and not much had been established regarding flow behaviour and prediction of scour depth around a pair or group of piers, an experimental study was planned and conducted to have further insight in this direction. Point wise, the target of study are:

(a) To study the flow mechanism around an isolated pier and its modification in the presence of other piers in its vicinity.

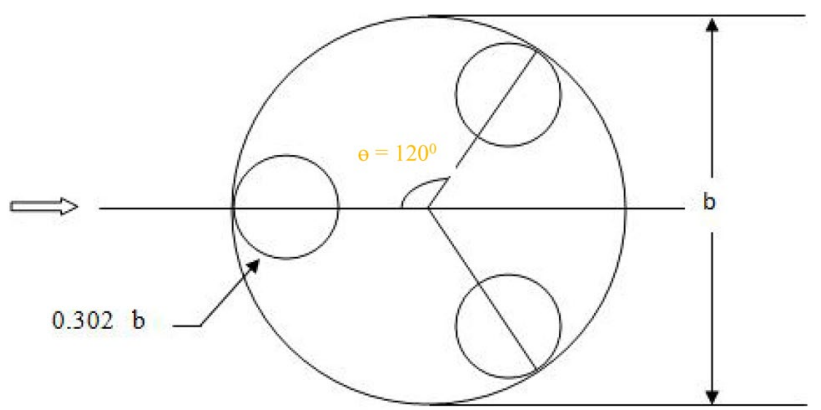

Fig. 2 Schematic of model piers showing the spacing and direction of flow as used by [16] 
(b) To examine the impact of spacing on the scour depth around pier models in Side by side, Tandem and Staggered arrangements.

(c) To validate the results using Ansys software and to compare them with those of the previous researchers.

\section{Experimental setup}

The experimental study was completed in the Hydraulic Laboratory of National Institute of Technology Kurukshetra. For the experiments a recirculating flume $15 \mathrm{~m}$ long, $0.40 \mathrm{~m}$ wide and $0.60 \mathrm{~m}$ high with a working Section $5 \mathrm{~m}$ away from the inlet pipe was used. The working section assuming it to be a section where the flow was fully established. For preparation of the hydraulic run the discharge was introduced into the flume and the $\mathrm{d} / \mathrm{s}$ control of flume was adjusted to create a desired depth of flow $(h>3 D)$. The flow thereafter was flowing over the downstream obstruction. The water surface was M2 type of curve. The water level in the flume was observed for a significant duration of time and observing no further change, it was declared to be steady and uniform. The outer walls of the recirculating flume were comprised of Perspex to facilitate visual observations and a tail gate at the end of flume to regulate the depth and flow velocity.
To simulate a river bed, fine sediment of mean diameter, $\mathrm{d}_{50}=0.30 \mathrm{~mm}$ was used. The critical flow velocity for the sediment entrainment was calculated using Laursen's critical velocity equation. The proportion $u / u_{c}$ turns out to be 0.89 . The sediment at this velocity was at the threshold of movement. Thus, two dimensional low height ripples were observed during the last quarter of the experimental run. Discharge values was varies from 0.010 to $0.01875 \mathrm{~m}^{3} / \mathrm{s}$. Three types of arrangements, i.e. Tandem, side by side and staggered were employed. The time duration of each test run was $300 \mathrm{~min}$ [18] as after this duration majority of the scour depth was seen to have been achieved. Thereafter, keeping in view the existing facilities, time span of $300 \mathrm{~min}$ was fixed for leading all tests of the examination.

Different details of the test set up and schematic of the recirculating flume are presented in Table 1 and Figs. 3 and $4 a-c$.

\subsection{Modeling analysis}

ANSYS18 was used to solve the CFD problem and then visualize the results in both ANSYS Fluent and in the CFDPost processing tool. The detail procedure used in Ansys for simulation is shown below.

Firstly create a fluent fluid flow analysis system in ANSYS Workbench. After that the geometry of the two

Table 1 Specifications of the flume, sediment, pier model and flow conditions

\begin{tabular}{|c|c|c|c|c|c|c|}
\hline $\begin{array}{l}\text { Dimension of flume } \\
(\mathrm{L}: \mathrm{B}: \mathrm{H})(\mathrm{m})\end{array}$ & $\begin{array}{l}\text { Mean size of sedi- } \\
\text { ment }(\mathrm{mm})\end{array}$ & $\begin{array}{l}\text { Shape and material } \\
\text { of pier }\end{array}$ & Size of pier (mm) & Flow velocity $(\mathrm{m} / \mathrm{s})$ & Flow depth $(\mathrm{mm})$ & Software used \\
\hline $15: 0.4: 0: 0.6$ & 0.30 & $\begin{array}{l}\text { Circular and } \\
\text { Wooden }\end{array}$ & 42 & 0.24 to 0.26 & 118 to 150 & Ansys 18.0 \\
\hline
\end{tabular}

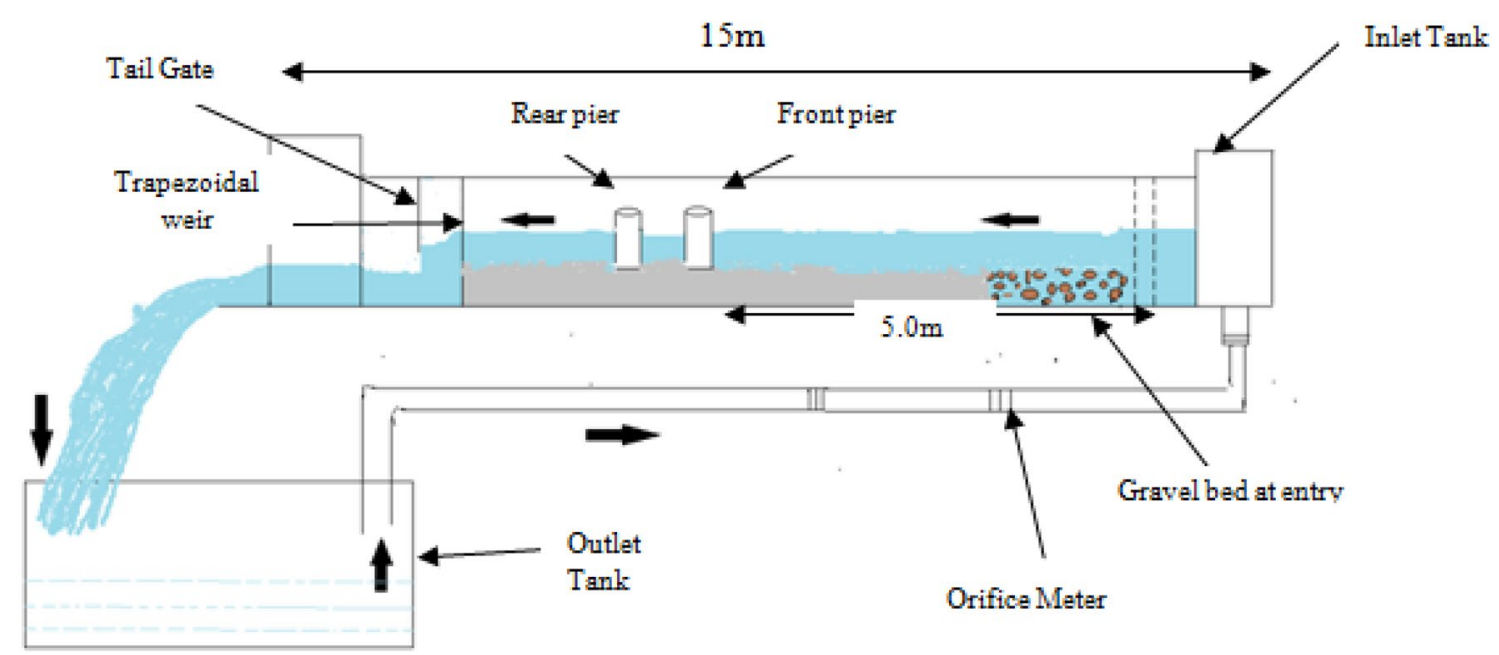

Fig. 3 A systematic line diagram of recirculating flume used in the experimental study 
Fig. 4 a Schematic line diagram of tandem arrangement for two pier models; Pier are one behind the other vis- $a$ - vis the flow direction ( $T=$ Clear spacing between the bridge pier models). $\mathbf{b}$ Schematic line diagram of side by side arrangement for two pier models $(s=$ Clear spacing between the bridge pier models). c Schematic line diagram of staggered arrangement of three pier models $(\mathrm{S}=$ Clear spacing between the two pier models in a staggered arrangement)

\section{(a)}

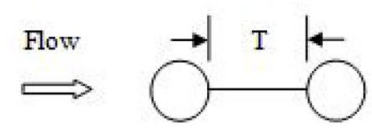

(b)

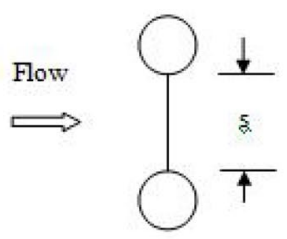

(c)

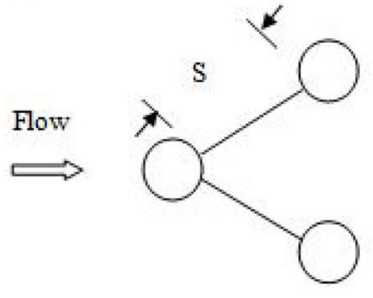

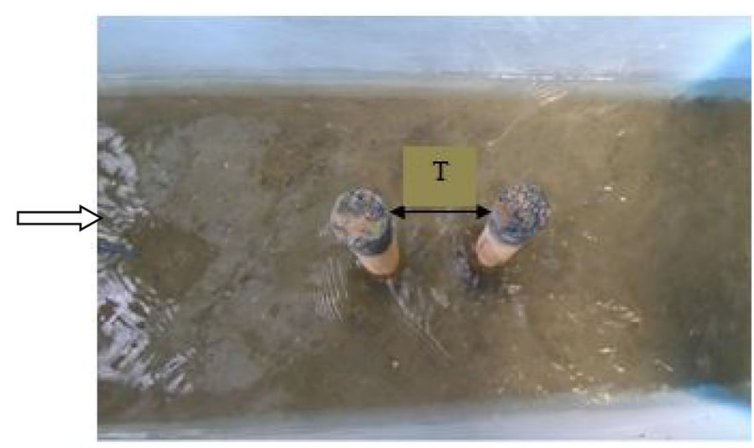
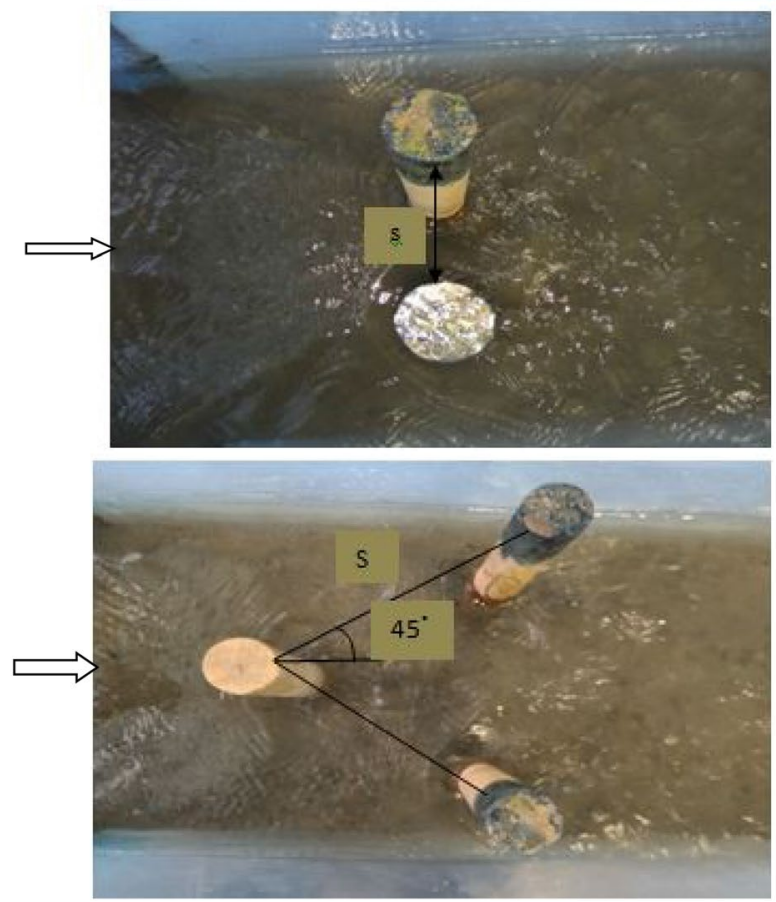

dimensional structure was designed using ANSYS Design Modeler. After completing the geometry, the meshing of the structure was to be done. In the next step the Set up the CFD simulation in ANSYS Fluent, which includes:-

(i) Setting material properties and boundary conditions (Inlet, outlet, walls and structure) for turbulent forced-convection problems were decided.

(ii) Initiating the calculation with residual plotting.

(iii) Calculating a solution using the pressure-based solver.

(iv) Examining the flow and temperature fields using ANSYS Fluent and CFD-Post.

(v) Create a copy of the original fluent fluid flow analysis system in ANSYS Workbench.

(vi) Change the geometry in ANSYS Design Modeler, using the duplicated system.

(vii) Regenerate the computational mesh.

(viii) Recalculate a solution in ANSYS Fluent.

\section{Results and discussion}

The results of the experiments carried out as per the scheme were arranged under different heads and were analysed and discussed. The results were also compared with the similar works of previous researchers.

\subsection{Tandem arrangement}

One pair of circular $42 \mathrm{~mm}$ diameter piers was placed along the centre line of the flume in a tandem arrangement at spacing of zero to sixteen times the diameter of the bridge pier. Being in a tandem arrangement, the piers were axi-symmetric to the flow with the angle of attack zero. The flow conditions and results related to tandem arrangement have been presented in Table 2 and Figs. 5, 6, 7 and 8. 
Table 2 Test results of the present study $(D=42 \mathrm{~mm})$ in a tandem arrangement

\begin{tabular}{|c|c|c|c|c|c|c|c|c|c|c|}
\hline \multirow[t]{2}{*}{$\begin{array}{l}\text { Number of } \\
\text { run }\end{array}$} & \multirow[t]{2}{*}{$\begin{array}{l}\text { Clear spac- } \\
\text { ing T/D }\end{array}$} & \multirow[t]{2}{*}{$\begin{array}{l}\text { Flow veloc- } \\
\text { ity }(\mathrm{m} / \mathrm{s})\end{array}$} & \multirow[t]{2}{*}{ Froud no. Fr } & \multirow[t]{2}{*}{$\begin{array}{l}\text { Flow depth } \\
\mathrm{h}(\mathrm{mm})\end{array}$} & \multicolumn{2}{|c|}{$\begin{array}{l}\text { Depth of Scour } \\
(\mathrm{mm})\end{array}$} & \multicolumn{2}{|c|}{$\begin{array}{l}\text { Depth of scour/pier } \\
\text { diameter }\end{array}$} & \multicolumn{2}{|c|}{$\begin{array}{l}\text { Scour depth non } \\
\text { dimensionalized } \\
\text { with flow depth }\end{array}$} \\
\hline & & & & & Hsu1 & Hsd1 & Hsu1/D & Hsd1/D & Hsu1/h & $\mathrm{Hsd} 1 / \mathrm{h}$ \\
\hline 1 & 0 & 0.26 & 0.238 & 121 & 55 & 55 & 1.31 & 1.31 & 0.45 & 0.45 \\
\hline 2 & 1 & 0.25 & 0.232 & 118 & 52 & 42 & 1.23 & 1.0 & 0.44 & 0.35 \\
\hline 3 & 2 & 0.26 & 0.238 & 121 & 53 & 40 & 1.26 & 0.95 & 0.43 & 0.33 \\
\hline 4 & 3 & 0.26 & 0.236 & 123 & 54 & 35 & 1.28 & 0.83 & 0.43 & 0.28 \\
\hline 5 & 4 & 0.25 & 0.227 & 123 & 41 & 32 & 0.97 & 0.76 & 0.33 & 0.25 \\
\hline 6 & 5 & 0.25 & 0.229 & 121 & 40 & 30 & 0.95 & 0.71 & 0.33 & 0.24 \\
\hline 7 & 6 & 0.26 & 0.231 & 129 & 34 & 28 & 0.81 & 0.66 & 0.26 & 0.21 \\
\hline 8 & 7 & 0.25 & 0.214 & 139 & 33 & 25 & 0.78 & 0.59 & 0.23 & 0.17 \\
\hline 9 & 10 & 0.25 & 0.217 & 135 & 31 & 30 & 0.72 & 0.71 & 0.22 & 0.22 \\
\hline 10 & 12 & 0.26 & 0.235 & 125 & 31 & 31 & 0.72 & 0.72 & 0.24 & 0.24 \\
\hline 11 & 14 & 0.26 & 0.236 & 124 & 30 & 30 & 0.71 & 0.71 & 0.24 & 0.24 \\
\hline 12 & 16 & 0.25 & 0.229 & 121 & 32 & 31 & 0.76 & 0.72 & 0.26 & 0.25 \\
\hline
\end{tabular}

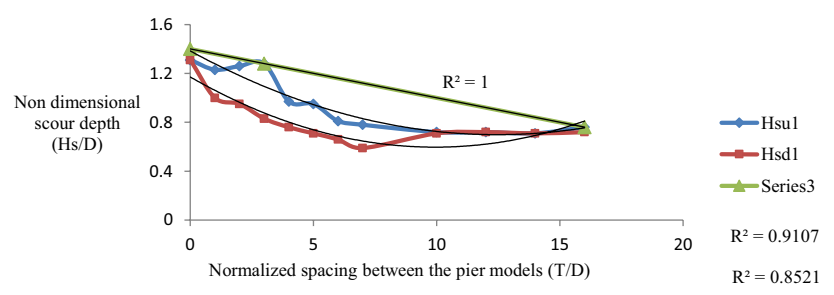

Fig. 5 Maximum scour depth at front of the upstream and downstream piers in tandem arrangement

Variation of scour depth with the spacing between the piers in tandem arrangement has been presented in Fig. 5. Figure shows that scour depth around the two piers with zero spacing between was $41 \%$ more than that of a single pier. The increase in scour depth could be due to the separation created at mid of the length of pier and also due to the additional length helping in the removal of more sediment at the upstream of the arrangement by creating a longer, oval shape scour hole. As the spacing between the piers increased, the scour depth began to decrease overall. Finally, when the spacing between the piers was sixteen times the diameter of the isolated bridge pier, both the piers showed individual behaviour of scouring. Although, the upstream pier registered higher scour depth in comparison to the downstream pier at any spacing. This is due to the fact that the upstream pier protects the downstream pier from excessive velocities and provides a shelter for the downstream pier, a phenomenon, identified by Hannah [15]. As the spacing between the piers increases the shielding effect of the front pier on the downstream pier reduces. After the removal of shielding effect both the piers show independent behaviour.
Equations representing the behaviour of the upstream and the downstream piers were $\mathrm{Hs} / \mathrm{D}=0.0044(\mathrm{~T} / \mathrm{D})^{2}$ 0.1101 (T/D) +1.3841 and $\mathrm{Hs} / \mathrm{D}=0.0058(\mathrm{~T} / \mathrm{D})^{2}-0.1155$ (T/D) +1.1711 , with $R^{2}$ values, of 0.9107 and 0.8521 . Further, if an enveloping curve covering all the values is plotted, it gives an equation, $\mathrm{Hs} / \mathrm{D}=-0.04(\mathrm{~T} / \mathrm{D})+1.4$.

A flow visualization study of the behavior of piers in tandem arrangement with 2D and 16D was carried out using ANSYS 18.0. The results have been show in Fig. 6a-d. While Fig. $6 a$ and $c$ show the velocity contours, the Fig. $6 b$ represents the velocity vector around the arrangement.

Figure 6a shows that when the spacing between the piers was $2 \mathrm{D}$ the piers showed high scour depth. The red zone around the piers is indicative of high magnitude of velocity which is around $0.34 \mathrm{~m} / \mathrm{s}$ and is responsible for higher scour depth. As the piers move towards the boundary wall of the flume the velocity of flow starts decreasing with a variation from 0.26 to $0.043 \mathrm{~m} / \mathrm{s}$ and is indicated by a shift in colour from green to blue. Figure $6 \mathrm{~b}$ shows the velocity vectors around the piers when the two piers are present in tandem arrangement at a clear spacing of 2D.

Figure $6 \mathrm{c}$ shows that initially, when the clear spacing between the piers was $2 D(D=$ Diameter of the pier) the pier indicated high scour depth. But as the distance between the piers increased the scour depth started to decrease. At a clear spacing of 16D the piers exhibited independent behaviour. During this process, the velocity of flow was observed to decrease from 0.36 to $0.34 \mathrm{~m} / \mathrm{s}$. Non interference of the two piers with $T / D=16$ is indicated by the uniform spacing of streak lines, Fig. $6 \mathrm{~d}$.

Figures 7 and 8 show a comparison between the present study and the previous studies of Rao [19] and Beg [20]. The figures showed that the behaviour of the front 

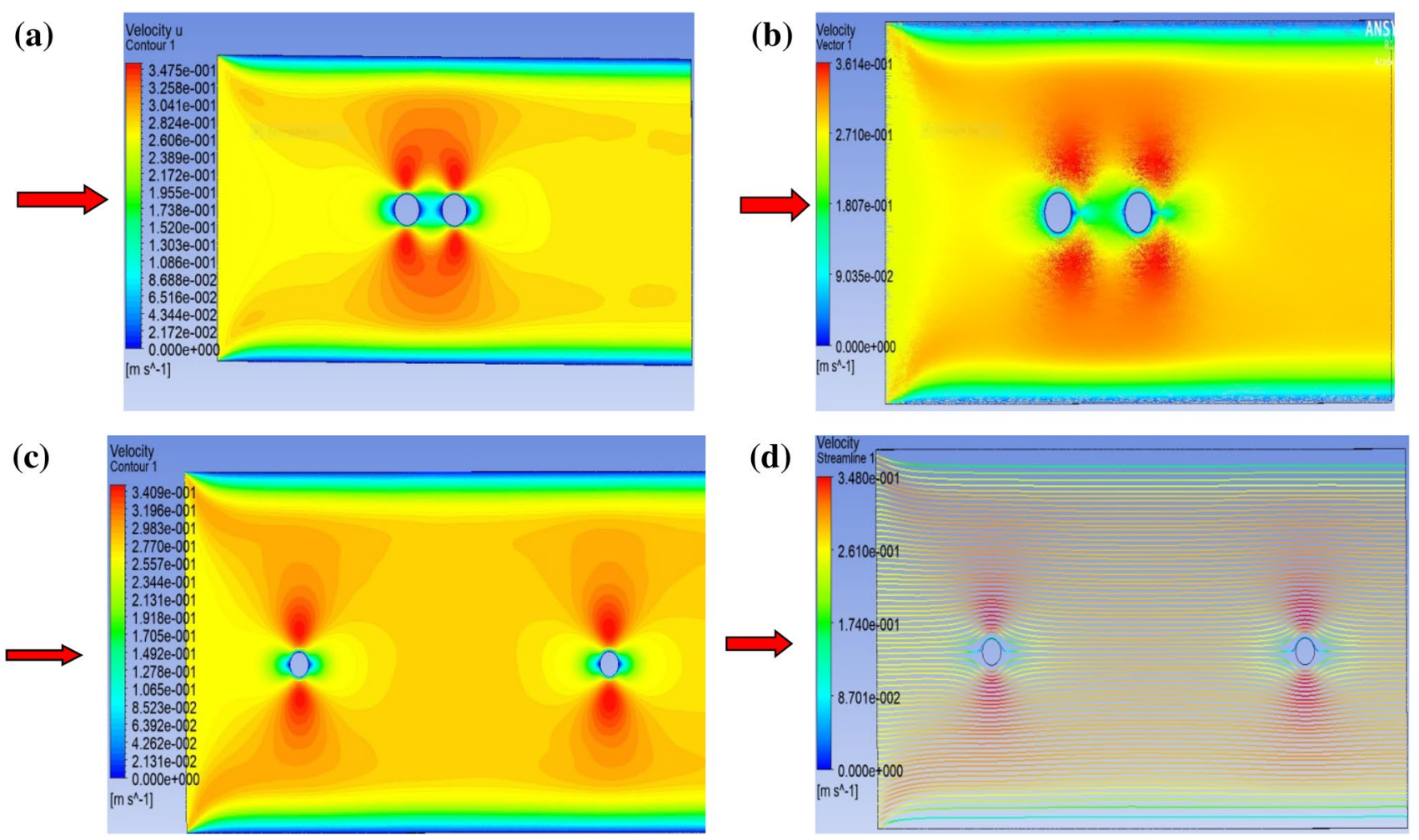

Fig. 6 a Flow visualization with the help of velocity contour using Ansys $(T / D=2)$. b Flow visualization with the help of velocity vector using Ansys $(T / D=2)$. c Flow visualization with the help of velocity

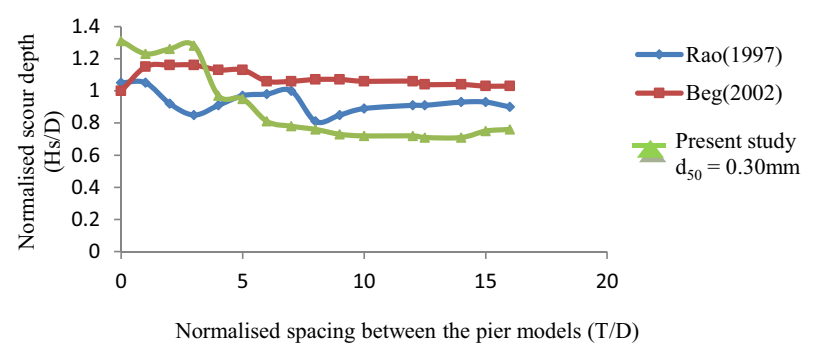

(upstream) and the rear (downstream) piers were comparative but different in magnitude. The difference in the magnitude could be possibly due to the difference in parameters like depth of flow and average size of the sediment. While the average size of sediment and depth of flow used by Beg [20] was $1.0 \mathrm{~mm}$ and $140 \mathrm{~mm}$, it was $0.30 \mathrm{~mm}$ and $125 \mathrm{~mm}$ in the present study. The upstream pier shows more scour depth in comparison to the downstream pier. The sediment motion from the base of the

Fig. 7 A comparison of the present results with Rao [19] and Beg [20] for the upstream pier

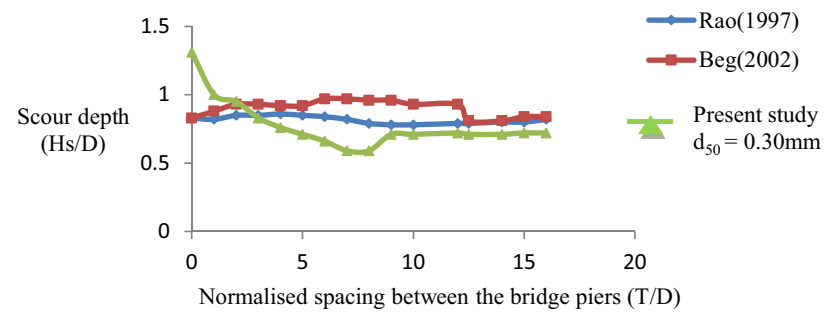

Fig. 8 A comparison of present results with Rao [19] and Beg [20] for the downstream pier

\section{SN Applied Sciences} front pier into the scour hole at the rear cylinder may lead to smaller scour depth in front of the rear pier [21, 22].

\subsection{Side by side arrangement}

A pair of circular $42 \mathrm{~mm}$ piers was employed for the study under this category. The piers were set at the centre of the flume in a side by side arrangement at a non dimensional spacing (s/D) of $0,0.5,1,1.5,2.0,2.5,3.0,3.5$ and 4 . The piers were so located in the sediment that the line joining the centre of the two piers was at right angles to the direction of flow and the centers of the two piers were located at the equal distance from the centre of flume. The results 
Table 3 Test results of the study in a side by side arrangement

\begin{tabular}{|c|c|c|c|c|c|c|c|c|c|c|}
\hline \multirow[t]{2}{*}{$\begin{array}{l}\text { Num- } \\
\text { ber of } \\
\text { run }\end{array}$} & \multirow[t]{2}{*}{$\begin{array}{l}\text { Clear } \\
\text { spacing } \\
\text { s/D }\end{array}$} & \multirow[t]{2}{*}{$\begin{array}{l}\text { Flow } \\
\text { velocity } \\
(\mathrm{m} / \mathrm{s})\end{array}$} & \multirow[t]{2}{*}{$\begin{array}{l}\text { Flow } \\
\text { depth } \mathrm{h} \\
(\mathrm{mm})\end{array}$} & \multirow[t]{2}{*}{ Froud no. Fr } & \multicolumn{2}{|c|}{$\begin{array}{l}\text { Depth } \\
\text { of scour } \\
(\mathrm{mm})\end{array}$} & \multicolumn{2}{|c|}{$\begin{array}{l}\text { Depth of scour/ } \\
\text { pier diameter }\end{array}$} & \multicolumn{2}{|c|}{$\begin{array}{l}\text { Scour depth } \\
\text { non dimension- } \\
\text { alized with flow } \\
\text { depth }\end{array}$} \\
\hline & & & & & Hsl1 & Hsr1 & $\mathrm{Hsl} 1 / \mathrm{D}$ & Hsr1/D & $\mathrm{Hsl} 1 / \mathrm{h}$ & $\mathrm{Hsr} 1 / \mathrm{h}$ \\
\hline 0 & 0 & 0.26 & 131 & 0.229 & 70 & 70 & 1.67 & 1.67 & 0.53 & 0.53 \\
\hline 1 & 0.5 & 0.26 & 132 & 0.228 & 40 & 43 & 0.95 & 1.02 & 0.30 & 0.33 \\
\hline 2 & 1.0 & 0.25 & 132 & 0.219 & 50 & 44 & 1.19 & 1.05 & 0.38 & 0.32 \\
\hline 3 & 1.5 & 0.26 & 130 & 0.230 & 42 & 42 & 1.00 & 1.0 & 0.32 & 0.32 \\
\hline 4 & 2.0 & 0.26 & 135 & 0.226 & 53 & 52 & 1.26 & 1.24 & 0.39 & 0.39 \\
\hline 5 & 2.5 & 0.26 & 136 & 0.225 & 43 & 45 & 1.02 & 1.07 & 0.32 & 0.33 \\
\hline 6 & 3.0 & 0.25 & 131 & 0.220 & 36 & 33 & 0.86 & 0.79 & 0.27 & 0.25 \\
\hline 7 & 3.5 & 0.26 & 147 & 0.217 & 36 & 36 & 0.86 & 0.86 & 0.24 & 0.24 \\
\hline 8 & 4.0 & 0.26 & 135 & 0.226 & 35 & 35 & 0.83 & 0.83 & 0.26 & 0.26 \\
\hline
\end{tabular}

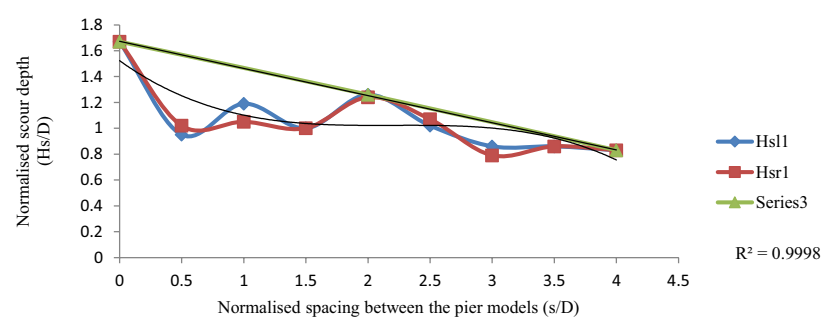

Fig. 9 Maximum scour depth at different pier spacing for the left and right pier in side by side arrangement

of study are presented in Table 3. Further, the plotting of results has been shown in Figs. 9 and 10a-c.

From Fig. 9 it tends to be seen that when the distance between the piers was $0 \mathrm{D}$ the piers behaved like a single pier of front projected size of double the diameter of the pier. Due to this projected area the scouring rate and magnitude was high. Scour depth around the set of two piers with zero spacing in between was $54 \%$ more than that of a single pier. Because the diameter of the bridge pier is the main factor to obstructs the flow around bridge piers. If the size of the obstruction was increased the scour rate will also increase. As the spacing increases, though the scour depth decreases, yet there is a definite reduction in the extent of the scour hole. The space created between two piers is responsible for releasing the pressure and hence a drop in scour depth. Further, when the distance between the bridge piers reached a value of $1.5 \mathrm{D}$, both the piers showed independent behavior and formed separate scour holes. Equations for the best fit line for the left and the right piers were $\mathrm{HS} / \mathrm{D}=-0.0473(\mathrm{~s} / \mathrm{D})^{3}+0.3128(\mathrm{~s} / \mathrm{D})^{2}-0$. $6867 \mathrm{~s}+1.523$ and $\mathrm{HS} / \mathrm{D}=-0.0531(\mathrm{~s} / \mathrm{D})^{3}+0.3554(\mathrm{~s} / \mathrm{D})^{2}-$ $0.7702 s+1.5418$. The two equations gave a coefficient of determination value, $R^{2}=0.64$ and 0.69 . Further, if an Enveloping curve covering maximum values is plotted, it gives $\mathrm{HS} / \mathrm{D}=-0.21(\mathrm{~s} / \mathrm{D})+1.6733$.

Using ANSYS a computational study of the behavior of piers in side by side arrangement was carried out. The results have been shown in Fig. 10a-c.

Figure 9 show that when the spacing between the piers was $\mathrm{OD}$ the scouring rate was very high. It is made clear that when the same arrangement was visualized using Ansys Fig. 10a a red zone was created around the bridge piers. It showed that the magnitude of the velocity around the piers got increased. The magnitude of the velocity was $0.45 \mathrm{~m} / \mathrm{s}$ on the sides of the piers as shown in Fig. 10a. But when the piers moved from centre to towards the (a)

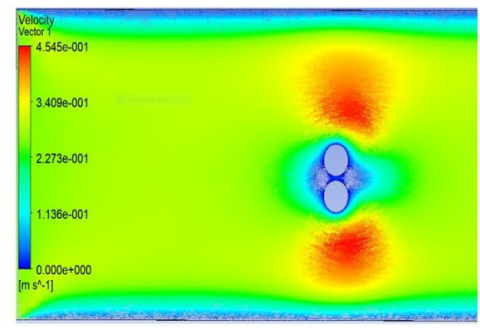

(b)

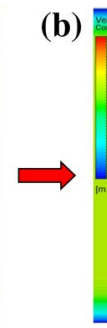

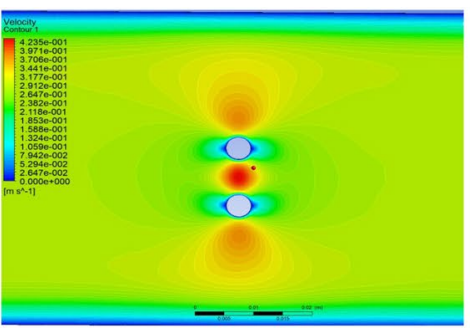

(c)

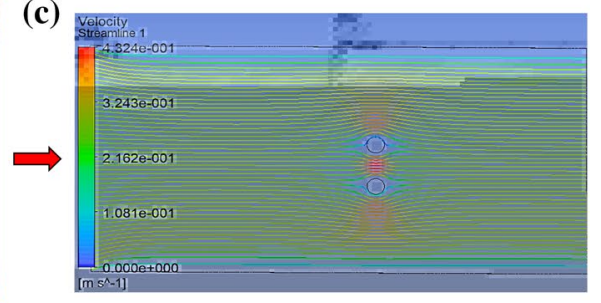

Fig. 10 a Flow visualization with the help of Velocity vector using Ansys $(s / D=0)$. b Flow visualization with the help of velocity contour using Ansys ( $s / D=1.5)$. c Flow visualization with the help of Stream lines using Ansys $(s / D=1.5)$ 
Table 4 Result of experimental study in a staggered arrangement

\begin{tabular}{|c|c|c|c|c|c|c|c|c|c|c|c|c|c|}
\hline \multirow[t]{2}{*}{$\begin{array}{l}\text { Number } \\
\text { of run }\end{array}$} & \multirow[t]{2}{*}{$\begin{array}{l}\text { Clear spacing } \\
\text { b/w piers S/D }\end{array}$} & \multirow[t]{2}{*}{$\begin{array}{l}\text { Velocity of } \\
\text { flow }(\mathrm{m} / \mathrm{s})\end{array}$} & \multirow{2}{*}{$\begin{array}{l}\text { Flow } \\
\text { depth } \mathrm{h} \\
(\mathrm{mm})\end{array}$} & \multirow{2}{*}{$\begin{array}{l}\text { Froude } \\
\text { number } \\
\text { (Fr) }\end{array}$} & \multicolumn{3}{|c|}{$\begin{array}{l}\text { Depth of scour } \\
(\mathrm{mm})\end{array}$} & \multicolumn{3}{|c|}{$\begin{array}{l}\text { Depth of scour/pier } \\
\text { diameter }\end{array}$} & \multicolumn{3}{|c|}{$\begin{array}{l}\text { Scour depth non dimen- } \\
\text { sionalized with flow depth }\end{array}$} \\
\hline & & & & & $\mathrm{Hsf}$ & Hsr1 & $\mathrm{Hsr2}$ & $\mathrm{Hsf} / \mathrm{D}$ & Hsr1/D & $\mathrm{Hsr2/D}$ & $(\mathrm{Hsf} / \mathrm{h})$ & (Hs1/h) & (Hs2/h) \\
\hline 1 & 0 & 0.26 & 150 & 0.21 & 62 & 62 & 62 & 1.48 & 1.48 & 1.48 & 0.41 & 0.41 & 0.41 \\
\hline 2 & 0.5 & 0.26 & 130 & 0.23 & 45 & 50 & 50 & 1.07 & 1.19 & 1.19 & 0.35 & 0.38 & 0.38 \\
\hline 3 & 1.0 & 0.26 & 146 & 0.21 & 44 & 56 & 56 & 1.05 & 1.33 & 1.33 & 0.30 & 0.38 & 0.38 \\
\hline 4 & 1.5 & 0.26 & 140 & 0.22 & 45 & 37 & 43 & 1.07 & 0.88 & 1.02 & 0.32 & 0.26 & 0.31 \\
\hline 5 & 2.0 & 0.26 & 137 & 0.22 & 43 & 36 & 40 & 1.02 & 0.86 & 0.95 & 0.31 & 0.26 & 0.29 \\
\hline 6 & 2.5 & 0.26 & 138 & 0.22 & 42 & 35 & 37 & 1.0 & 0.83 & 0.88 & 0.30 & 0.25 & 0.27 \\
\hline 7 & 3.0 & 0.26 & 150 & 0.21 & 35 & 35 & 40 & 0.83 & 0.83 & 0.95 & 0.23 & 0.23 & 0.27 \\
\hline 8 & 3.5 & 0.26 & 142 & 0.22 & 30 & 30 & 35 & 0.71 & 0.71 & 0.83 & 0.21 & 0.21 & 0.25 \\
\hline 9 & 4.0 & 0.26 & 138 & 0.22 & 37 & 30 & 36 & 0.88 & 0.71 & 0.86 & 0.27 & 0.22 & 0.26 \\
\hline
\end{tabular}

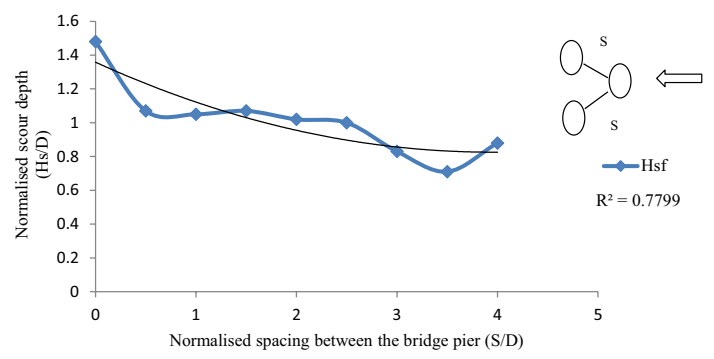

Fig. 11 Maximum scour depth at different spacing for the front pier in staggered arrangement

boundary walls the velocity of flow started to decrease and it varied from 0.45 to $0.11 \mathrm{~m} / \mathrm{s}$. In Fig. $10 \mathrm{~b}$ where the spacing between the piers was $1.5 \mathrm{D}$, a red zone indicating high velocity in comparison to the piers was present at a spacing of $0 \mathrm{D}$ and the magnitude of the velocity was $0.42 \mathrm{~m} / \mathrm{s}$. In this case the velocity varied from 0.31 to $0.42 \mathrm{~m} / \mathrm{s}$. Figure $10 \mathrm{c}$ shows the uniformity of streak lines around the bridge pier when two piers were present in the side by side arrangement at spacing of 1.5D.

Finally, it is inferred that as the spacing between the piers increases the scour depth decreases, thereby establishing the adverse interference effect of piers in close proximity.

\section{Staggered arrangement}

A group of three circular $42 \mathrm{~mm}$ diameter piers arranged in two rows was placed for the study under this head. The piers were installed in the centre of the channel in a staggered arrangement at a non dimensional spacing from 1 to 4 in increments of 0.5 times the diameter of the isolated bridge pier. Being in staggered arrangement, the rear piers were placed at an angle of $45^{\circ}$ w.r.t the front pier.

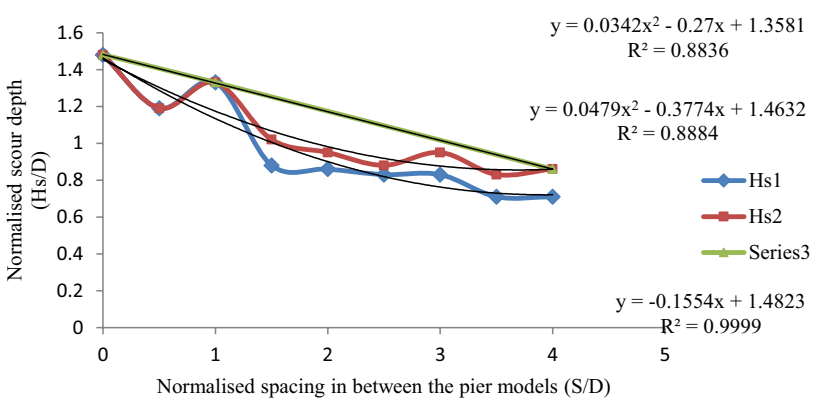

Fig. 12 Maximum scour depth at different spacing for the rear pier in staggered arrangement

The results related to staggered arrangement have been presented in Table 4 and Figs. 11, 12, 13 and 14 and 15.

From Fig. 11 it is observed that when the spacing between the piers was $S / D=0$, the pier showed high scour depth. But when spacing between the bridge piers increase in staggered arrangement the front pier showed a decreasing pattern of scour depth. The scour depth around front pier with zero spacing in between was $48 \%$ more than that of a single pier. Equation for the best fit line for the upstream pier was $\mathrm{Hs} / \mathrm{D}=0.0342(\mathrm{~S} / \mathrm{D})^{2}-0.27(\mathrm{~S} / \mathrm{D})$ +1.3581 . The equation gave a coefficient of determination, $R^{2}$ of 0.779 . Though it is not a very good coefficient of determination yet for scour studies, it may be accepted. Further, if an Enveloping curve covering maximum values is plotted, it gives $H_{S} / D=-0.1554(S / D)+1.4823$.

From Fig. 12 it may be seen that when three piers are present at a non-dimensional spacing of $0 D$, the piers behave like a single pier and the arrangement showed more scour depth. But when, the spacing between the piers is increased, the rear end piers showed lesser scour depth as compared to the front pier but both the piers showed a decreasing pattern of scour depth. At a non dimensional spacing of $2.5 \mathrm{D}$, all the three piers showed 

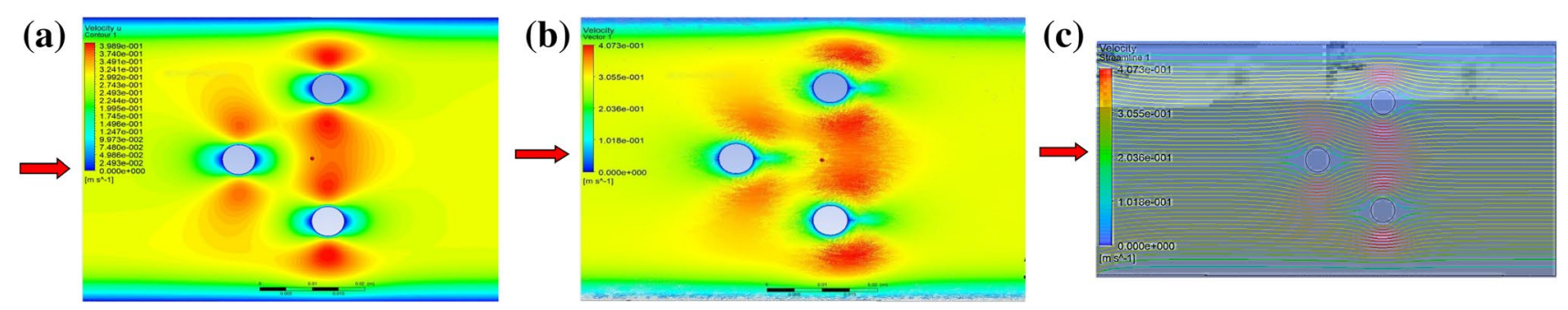

Fig. 13 a Flow visualization with the help of velocity contour using ANSYS $(S / D=2.5)$. b Flow visualization with the help of velocity vector using ANSYS $(S / D=2.5)$. c Flow visualization with the help of Stream lines using ANSYS $(S / D=2.5)$

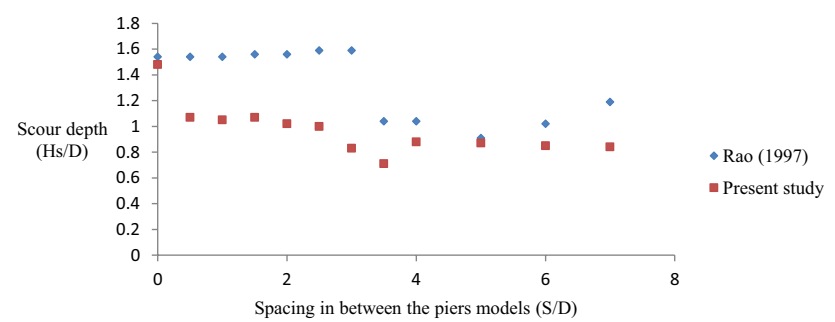

Fig. 14 A comparison present results with Rao [19] for the upstream pier in staggered arrangement

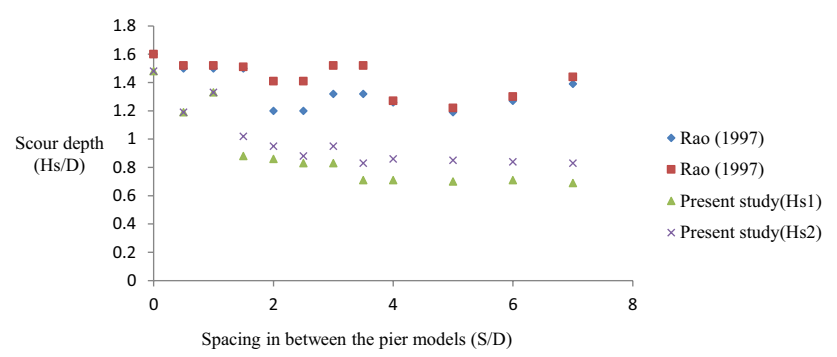

Fig. 15 A comparison of present results with Rao [19] for the downstream piers in staggered arrangement

independent behaviour. Because after that front pier as well as the rear piers behaved independently. Equation for the best fit line for the rear piers was $H S / D=0.0342$ $(S / D)^{2}-0.27(S / D)+1.3581$ and $H S / D=0.0479(S / D) 2-0$. $3774(S / D)+1.4632$. The two equations gave a value, $R^{2}$ of 0.8836 and 0.888 respectively. Figure 13a gives a pictorial view of velocity contours drawn in ANSYS 18.0 in staggered arrangement when three piers were placed at a non dimensional spacing of $2.5 \mathrm{D}(\mathrm{S} / \mathrm{D}=2.5)$. A red colour zone indicating high velocity around the bridge pier has been created. The pattern is explained through the statement of Hannah [15] "If the area around the piers decreases velocity of flow increases simultaneously". But when the piers move towards the sides of the flume, velocity of flow decreases. The flow velocity varies from 0.40 to
$0.024 \mathrm{~m} / \mathrm{s}$ from centre of the flume to the boundary wall, respectively.

Figure $13 \mathrm{~b}$ gives the velocity vectors around the piers in the staggered arrangement. Similarly, the stream lines showing the pattern of flow around bridge piers in staggered arrangement are presented in Fig. 13c. From this figure it may be seen that the spacing between the flow lines was close to the piers however when the spacing between the piers was expanded, the separation between the flow lines also expanded.

Figure 14 shows a comparison of the results of the present investigation with the studies of Rao [19]. Both the investigations show that at the front pier indicates more scour depth in comparison to the rear bridge pier. The difference in the magnitude of the scour depth in the two studies might be because of the size of the bridge pier models and the median size of the sediment. In the present study, piers of size $42 \mathrm{~mm}$ were used and in the study of Rao [19], $50 \mathrm{~mm}$ sized piers were used. Similarly, size of sediment in the present study and Rao [19] was $0.30 \mathrm{~mm}$ and $0.16 \mathrm{~mm}$ respectively. Similar patterns of the scour depth were observed for the rear piers have been shown in Fig. 15. Summary of the purposed equations for the three arrangements were shown in Table 5.

\section{Scour depth in non-uniform flow velocity (hydrographic run)}

Four types of experiments were performed under this category, i.e. single pier, Tandem, side by side and piers in staggered arrangement. However graphical presentation of variation of certain parameters is being given for a single pier only. The discharge in the flume was increased in steps of half an hour on reaching the peak, the discharge was decreased in the same way. The experimental results of the scour depth along with the flow conditions of discharge per unit width of flume, velocity of flow and flow depth are being presented in Fig. 16a-d. The results of the non uniform flow are presented in Table 6 . 
Table 5 Different types of equations used in the experimental study

\begin{tabular}{lllll}
\hline Serial no & Arrangement & Piers & Equation & $\mathrm{R}^{2}$ \\
\hline 1 & Tandem & Upstream & $\mathrm{Hs} / \mathrm{D}=0.0044(\mathrm{~T} / \mathrm{D}) 2-0.1101(\mathrm{~T} / \mathrm{D})+1.3841$ & 0.9107 \\
& & Downstream & $\mathrm{Hs} / \mathrm{D}=0.0058(\mathrm{~T} / \mathrm{D}) 2-0.1155(\mathrm{~T} / \mathrm{D})+1.1711$, & 0.8521 \\
2 & Left & $\mathrm{HS} / \mathrm{D}=-0.0473(\mathrm{~s} / \mathrm{D}) 3+0.3128(\mathrm{~s} / \mathrm{D}) 2-0.6867 \mathrm{~s}+1.523$ \\
& Side by side & $\mathrm{HS} / \mathrm{D}=-0.0531(\mathrm{~s} / \mathrm{D}) 3+0.3554(\mathrm{~s} / \mathrm{D}) 2-0.7702 \mathrm{~s}+1.5418$ & 0.640 \\
3 & & $\mathrm{Hs} / \mathrm{D}=0.0342(\mathrm{~S} / \mathrm{D}) 2-0.27(\mathrm{~S} / \mathrm{D})+1.3581$ & 0.779 \\
& Staggered & Upstream & $\mathrm{HS} / \mathrm{D}=0.0342(\mathrm{~S} / \mathrm{D}) 2-0.27(\mathrm{~S} / \mathrm{D})+1.3581$ & 0.8836 \\
& & Rear 1 & $\mathrm{HS} / \mathrm{D}=0.0479(\mathrm{~S} / \mathrm{D}) 2-0.3774(\mathrm{~S} / \mathrm{D})+1.4632$ & 0.888 \\
\hline
\end{tabular}

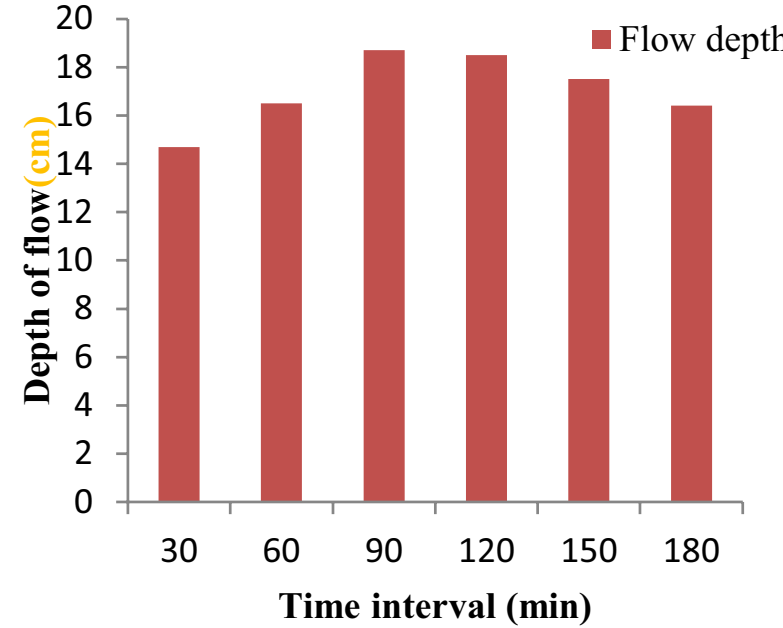

(a)

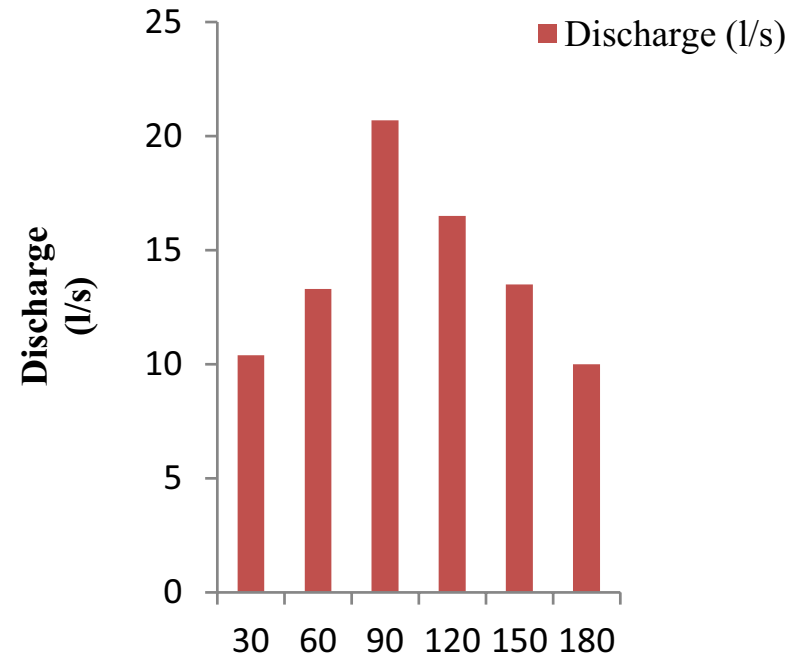

Time interval (min)

(c)

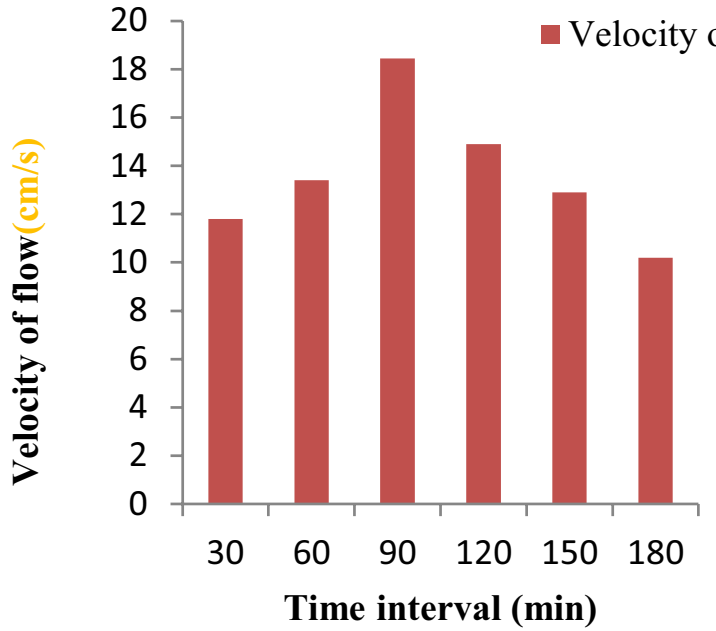

(b)

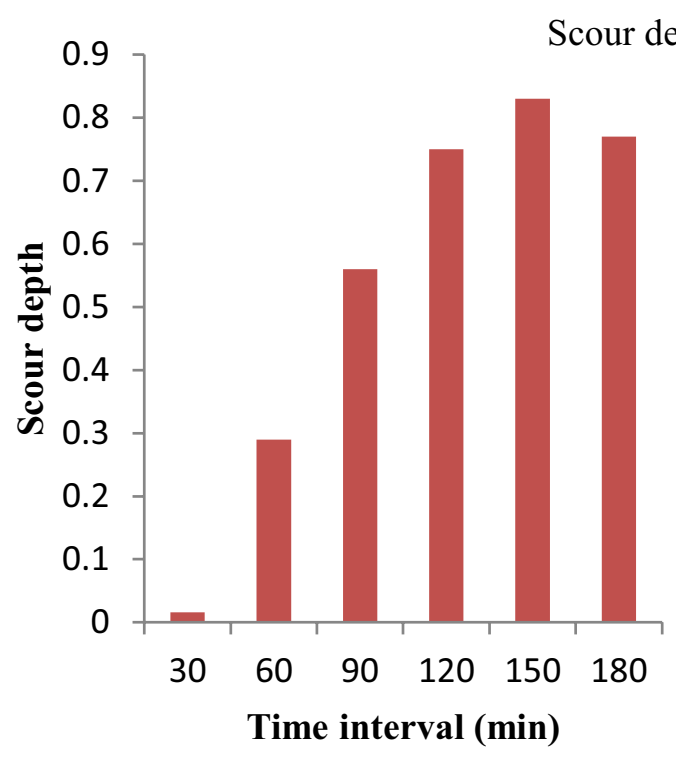

(d)

Fig. 16 Effects of change in velocity, depth of flow on scour depth shows using hydrographic run (single pier) 
Table 6 Results of non uniform flow conditions

\begin{tabular}{llllll}
\hline S. no. & Time Interval $(\mathrm{min})$ & $\begin{array}{l}\text { Flow depth } \\
(\mathrm{cm})\end{array}$ & $\begin{array}{l}\text { Velocity of flow } \\
(\mathrm{m} / \mathrm{s})\end{array}$ & Discharge $(\mathrm{l} / \mathrm{s})$ & Scour depth \\
\hline 1 & $0-30$ & 14.7 & 11.80 & 10.4 & 0.01 \\
2 & $30-60$ & 16.5 & 13.40 & 13.3 & 0.29 \\
3 & $60-90$ & 18.7 & 18.45 & 20.7 & 0.56 \\
4 & $90-120$ & 18.5 & 14.90 & 16.5 & 0.75 \\
5 & $120-150$ & 17.5 & 12.90 & 13.5 & 0.83 \\
6 & $150-180$ & 16.4 & 10.20 & 10.0 & 0.77 \\
\hline
\end{tabular}

\section{Conclusions}

The major conclusions of the present study are as per the following:

\subsection{Tandem arrangement when two piers are present in a line}

- The scour depth at the upstream pier was always greater than that of the downstream pier.

- When T/D $>4$, the maximum scour depths at the rear pier began to decrease and finally become equivalent to the scour depth of a single pier when the spacing T/D was equal to $16 \mathrm{D}$ ( $\mathrm{D}=$ Diameter of pier).

- The maximum scour depths observed for two piers in a line is found at spacing (T/D) equals to zero times the diameter of the pier and it was $41 \%$ greater than that of the single pier.

\subsection{Side by side arrangement}

- The scour depth in front of piers in case of side by side arrangement was the maximum among all the three arrangements experimented upon during the study.

- When $s / D=0$ the both the piers behave like a single pier and effective diameter of pier become doubled. Thus, at that time the scour depth was observed to be the most extreme.

- When $s / D>1.5$, both the piers forms their individual scour holes and cannot interfere with each other. Both the piers show independent behaviour.

- The maximum scour depths observed for two piers in side by side arrangement is found at a spacing (T/D) equal to zero times the diameter of the bridge pier and it was $54 \%$ greater than that of an isolated bridge pier.

\subsection{Staggered arrangement}

- When normalised spacing, S/D $>2.5$ between the piers the scour depth around the piers start decreasing.

- When $S / D=0$, all the three piers behave like a single pier and the maximum scour depth around the piers was $48 \%$ greater than that of an isolated bridge pier scour depth.

Acknowledgements First author would like to thank the Human Resource Development Group (CSIR) Ministry of Science and Technology, India for providing financial support for the doctoral programme.

\section{Compliance with ethical standards}

Conflict of interest On behalf of all the authors, it is stated that there is no conflict of interest.

\section{References}

1. Wardhana K, Hadipriono FC (2003) Analysis of recent bridge failures in the United States. J Perform Constr Facil ASCE 17(3):144-150

2. Laursen EM, Toch A (1956) Scour around bridge piers and abutments, vol 4. lowa Highway Research Board, Bureau of Public Roads, lowa

3. Melville BW (1975) Local scour at bridge sites. School of Engineering, University of Auckland, Auckland

4. Ettema R (1980) Scour at bridge piers. Dissertation, Department of Civil Engineering, University of Auckland

5. Melville BW, Sutherland AJ (1988) Design method for local scour at bridge piers. J Hydraul Eng Proc ASCE 14(10)

6. Breusers HNC, Raudkivi AJ (1991) Scouring. Hydraulic structure design Manual. Balkema, Rotterdam-Brookefield

7. Dey S, Bose SK, Sastry GLN (1995) Clear water scour at circular piers: a model. J Hydraul Eng 121:869-876

8. Hoffman GJCM, Verheij HJ (1997) Scour manual. CRC Press, Hoboken

9. Setia B (1997) Scour around bridge piers: mechanism and protection. Dissertation, Department of Civil Engineering, Indian Institute of Technology, Kanpur, India

10. Muzzamil M, Gangadharaiah T (2003) The Mean characteristics of horse shoe vortex at a cylindrical pier. J Hydraul Res 41(3):285-297

11. Barbhuiya KA, Dey S (2003) Local scour at abutments. A review. Sadhana 29(5):49-476

12. Gangarudraiah V, Gangadharaiah T, Ramaswamyiyenger J (2012) Vortex scouring process around bridge pier with a caisson. J Hydraul Res 49(3):378-383

13. Ismail Z, Jumain M, Sidek F, Wahab AK, Ibrahim Z, Jmael M (2013) Scour investigation around single and two piers side by side arrangement. Int J Res Eng Technol 2(10):2319 
14. Malik R, Setia B (2018) Local scour around closely placed bridge piers. ISH J Hydraul Eng. https://doi.org/10.1080/09715 010.2018 .1559772

15. Hannah CR (1978) Scour at pile groups. University of Canterbury, N. Z., Civil Engineering Research REP. No., 78-3, 92

16. Haghighat et al (1994) Clear water scour around bridge pier group. J Hydraul Eng ASCE 120:1309-1318

17. Khaple et al (2016) Interference of an upstream pier on local scour at downstream piers. J Acta Geophys 65(1):29-46

18. Setia B (2008) Equilibrium scour depth time. In: 3rd IASME/ WSEAS international conference on water resources, hydraulics \& hydrology, University of Cambridge, UK, pp 114-117

19. Rao GP (1997) Interference on local scour around bridge piers. Dissertation, Department of Civil Engineering, Indian Institute of Technology, Kanpur, India
20. Beg M (2002) Mutual interference around bridge piers on local scour. Civil Engineering Department Z. H. College of Engineering and Technology, A.M.U., Aligarh

21. Ferraro D, Tafarojnoruz A, Gaudio R, Cardoso AH (2013) Effects of pile cap thickness on the maximum scour depth at a complex pier. J Hydraul Eng ASCE 139(5):482-491

22. Tafarojnoruz A, Gaudio R, Calomino F (2012) Bridge pier scour mitigation under steady and unsteady flow conditions. Acta Geophys 60(4):1076-1097

Publisher's Note Springer Nature remains neutral with regard to jurisdictional claims in published maps and institutional affiliations. 